\title{
Life origin on earth, what is the right answer?
}

\begin{abstract}
Why and how living forms, such as human beings, have been originated from a barely life planet into the multiple and highly-intelligent living existence on Earth have been fascinated by large population of readers and scientific investigators. Apart from derivative arguments from Darwin's theory, some detailed evolutionary hypotheses and steps have been stated and discussed-including the evolutionary step of genetic information duplication (prebiotic broth), outsider living-form landing, volcanic eruption in deeper sea and cooperative biological hypothesis. In this perspective article, we discuss the advantages and limitations of these life-origin hypotheses and crucial steps in evolution progression of life creation on Earth. The major objective of this article is to elucidate the different characters of many existing hypotheses.
\end{abstract}

Keywords: human evolution, rna-origination, systems biology, genetic information system
Volume 2 Issue 2 - 2017

\author{
Da Yong Lu,' Ting Ren Lu, ${ }^{2}$ Shan Cao, ${ }^{3}$ \\ Nagendra Sastry Yarla,' Yi Lu ${ }^{4}$ \\ 'Department of Molecular biology, Shanghai University, China \\ 2Department of Molecular biology, GITAM University, India \\ ${ }^{3}$ Department of Molecular biology, Kyoto University of Art \& \\ Design, Japans \\ ${ }^{4}$ Department of Molecular biology, Shanghai Ocean University, \\ China
}

Correspondence: Da Yong Lu, Department of Molecular biology, Shanghai University, China, Email ludayong@shu.edu.cn

Received: November 30, 2016 | Published: March 24, 2017

\section{Backgrounds}

Why and how our living-bodies, such as human beings, have been originated from a barely life planet into the highly-intelligent life existing Earth have been interested and pursued by large groups of fans and investigation populations..$^{1-2}$ In order to serve these people, a short review is given.

\section{Current popular hypotheses}

Current popular hypotheses of life origin on Earth are divided as
a. RNA world hypothesis..$^{3-4}$
b. Volcanic eruptions under deep sea hypothesis. ${ }^{5-6}$
c. Meteoroid or alien landing hypothesis. ${ }^{6}$
d. Cooperative biologic models. ${ }^{7-8}$
e. Motility at the origin of life ${ }^{9}$ and so on.

\section{RNA world hypothesis}

Greatly influenced by Darwin's book, the majority topics in life origin is the RNA-world evolution model that utilize models of gradual evolution by natural selection Ogel UK. ${ }^{3-4}$ After the formation of this RNA world hypothesis, the experimental data showed that pro-RNA and/or pro-peptide can be synthesized in environmental conditions of early earth. ${ }^{10-12}$ Its synthetic processes are somewhat like PCR of biochemical studies.

There has been DNA-, RNA- and protein-originated evolution hypotheses regarding the first genetic information having been duplicated and translated. There are a lot of experimental data can be used to support two possibilities of genetic material duplication. ${ }^{10-12}$ For example, we simulate genetic information duplication in the presence of one type of genetic materials.

But this likes "chicken-or-the-egg" dilemma concerning from which genetic polymer comes first and we cannot tell in sure which topic is the right answer. Since genetic information duplication is the foremost important step to copy a life with integrity and persistency, it is widely accepted that this process is a crucial step in evolution progression for life creation. In this article, we try to overview these hypotheses and discuss one of the crucial factors for evolution, formation rate or turn-over speeds of different genetic materials (DNA, RNA and protein), to further suggest an important role RNA may take in life origin on Earth. Also, we try to discuss one of strategies of justifying these hypothesis and theory of whether through DNA, RNA, or protein-based life-evolution by using simulating system of different "prehistoric broths" and discover their relations by simulated calculations.

Most of people believe life is transformed from a world of very few types of simplest inorganic materials to nowadays tremendously diversified biomolecular world. These evolutions, we generally agree, are phase-wise, and undergo evolution step-by-step. In the initial step, materials on the Earth may transform from inorganic materials into organic molecules containing mixtures that are now called "a prebiotic broth" "-4 Then the Earth comes to an important stage of genetic reproductions from these "prebiotic broths" into a genetic informational reproducible stage.

\section{Organic compound origin and synthesis deriving volcanic eruptions from deep sea}

Organic compound origin and synthesis deriving volcanic eruptions from deep sea was hypothesized by Wächtershäuser (Germany). ${ }^{5-6}$ This hypothesis exists quite long times but has less experimental work owing to limitations of current technical advancements.

\section{Meteoroid or alien landing hypothesis}

Meteoroid or alien landing hypothesis is one of the most possibility arguments. Though widely neglected by critics, we still think it is one of the most feasible arguments worldwide until now. It is reliant on belief or science. This argument needs long time to debate (Figure 1).

\section{Others}

Beside these three arguments, other new hypotheses still need to be evaluated. ${ }^{7-10}$ We do not want to reiterated them here owing to space constrain. 


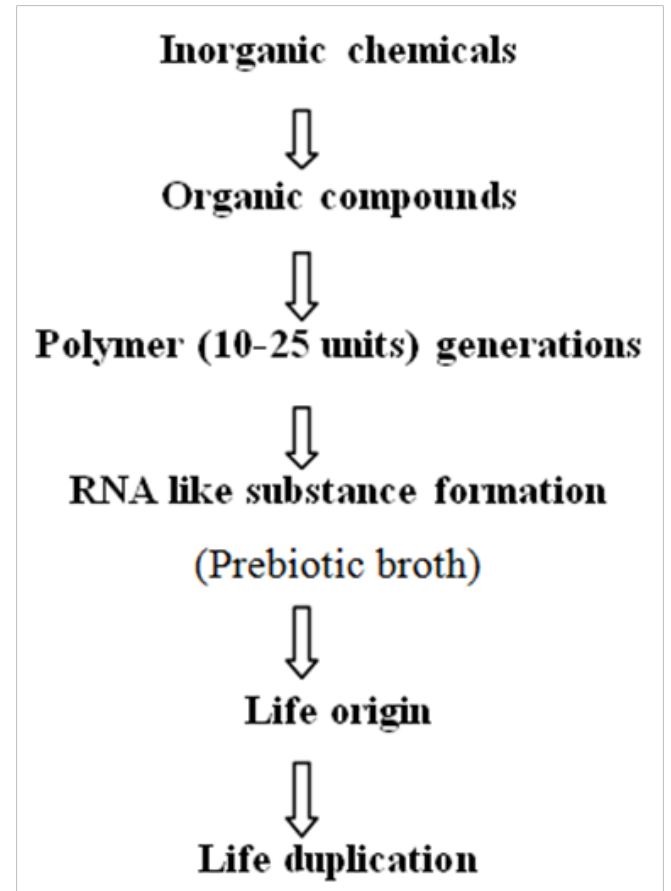

Figure I Schematic diagram of life origin and duplication by RNA world hypothesis.

\section{Discussion}

Present findings and arguments support each form of life-evolution theories while they are still reliant on solid experimental data and/or natural clues. There are a lot of experiment data can be used to support these possibilities. Some key-processes such as the matter of speed and a step of stability that can speak personally. We need some wider visions (Figure 2).

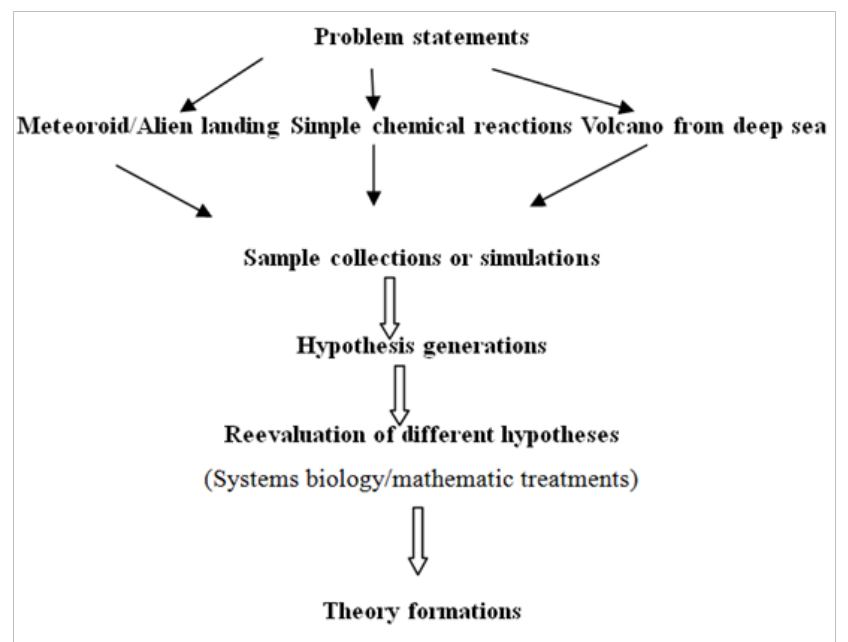

Figure 2 The pathways that hypotheses and speculations towards origin of life may be resolved.

\section{Future direction}

Now, we begin to believe that all three genetic materials can all be present at the era of genetic information duplication. We made this conclusion by finding many reports that materials promoting genetic replication such as ribosome are a mixture of RNA and proteins. It is possible two; three genetic materials, cell membrane, different energy donors and others cooperatively duplicate their selves' right at its beginning. ${ }^{7-8}$

\section{Conclusion}

Life origin on earth is unknown to us. This editorial gives our visions to this matter. Certainly, besides biologists, mathematical/ physics-majored scientists are also useful to take parts these researches and final offer their contributions. ${ }^{15-18}$ Let's decide what is the right answer.

\section{Acknowledgements}

None.

\section{Conflict of interest}

Author declares that there is no conflict of interest.

\section{References}

1. Darwin C. On the origin of Species. London; Murray: 1859.

2. Crick FHC. Origin of the genetic code. Nature.1967;213:119.

3. Orgel LE. Molecular replication. Nature. 1992;358:203-209.

4. Orgel LE, Crick FHC. Anticipating an RNA world some past speculations on the origin of life: where are they today? FASEB J. 1993;7(1):238-239.

5. Wächtershäuser G. Before enzymes and templates: theory of surface metabolism. Microbiological Rev. 1988;52(4):452-484.

6. Wächtershäuser G. On the chemistry and evolution of the pioneer organism. Chemistry \& Biodiversity. 2007;4(4):584-602.

7. Lu DY, Lu TR, Wu HY. Origin of life, RNA world or alternate RNA world. Cold Spring Harb Perspect Biol. 2012;1(1):e102.

8. Lu DY, Lu TR, Wu HY. Origins of life, a new cooperative model. Cell \& Developmental Biology. 2012;1(4):e109.

9. Froese T, Virgo N, Ikegami T. Motility at the origin of life, its characterization and a model. Artificial Life. 2014;20(1):55-76.

10. De Duve C. Chemistry and selection. Chemistry \& Biodiversity. 2007;4(4):574-583.

11. Zimmer C. Did DNA come from viruses? Science. 2006;312(5775):870-872.

12. Engelhart AE, Hud NV. Primitive genetic polymers. Cold Spring Harb Perspect Biol. 2010;2(12):a002196.

13. Lupi O, Dadalti P, Sanberg PR. Are prions related to the emergence of early life? Med Hypotheses. 2006;67(5):1027-1033.

14. Lupi O, Dadalti P, Good heart C. Did the first virus self-assemble from self-replicating prions proteins and RNA. Med Hypotheses. 2007;69(4):724-730.

15. Francis BR. An alternative to the RNA world hypothesis. Trends in Evolutionary Biology. 2011;3:e2.

16. Culley AI, Lang AS, Suttle CA. Metagenomic analysis of coastal RNA virus communities. Science. 2006;312(5781):1795-1798.

17. Lu DY, Lu TR. Mathematics or physics-majored students on the biomedical fields, insiders or outsiders? Metabolomics. 2015;5(4):e142.

18. Lu DY, Wu HY, Lu TR, et al. Updating biomedical studies by recruiting more mathematics or physics-majored talents. Metabolomics. 2016;6(2):e148. 